ORIGINAL ARTICLE

\title{
Materialism, conspicuous consumption, and brand engagement in self-concept: a study of teenagers
}

\author{
Magdalena Kolańska-Stronka (1D ${ }^{1 \text { A,B,C,D,E,F,G }}$, Oleg Gorbaniuk (D) 2,3 A,B,C,D,E,F \\ 1: Institute of Psychology, University of Zielona Góra, Zielona Góra, Poland \\ 2: Institute of Psychology, John Paul II Catholic University of Lublin, Lublin, Poland \\ 3: Faculty of Psychology, University of Economics and Human Sciences, Warsaw, Poland
}

\section{BACKGROUND}

Contemporary adolescents, also known as Generation Z, are an important group of consumers due to the role they play in today's economy. The present study investigates the relationship between materialism and brand engagement in self-concept (BESC) and whether conspicuous consumption is a mediator of this relationship in early, middle, and late adolescence.

\section{PARTICIPANTS AND PROCEDURE}

The participants were 581 students from Poland, aged 13 to $17(M=15$ years, $S D=1.42) ; 51.6 \%$ of them were girls. Data were gathered using a demographic information form, the Youth Materialism Scale, the Conspicuous Consumption Scale, and a BESC Scale, completed during personal interviews.

\section{RESULTS}

The study indicated an association of higher materialism and higher conspicuous consumption with a higher level of BESC, where conspicuous consumption acts as a mediator of the correlation between materialism and BESC. Age also moderates this mediation, i.e., the older the teenagers are, the weaker is the analyzed mediation effect.

\section{CONCLUSIONS}

The research is part of an essential step in understanding the mechanism of BESC by testing a moderated mediation model in teenagers.

\section{KEY WORDS}

teenagers; materialism, conspicuous consumption; brand engagement in self-concept 


\section{BACKGROUND}

Contemporary adolescents, also known as Generation Z (National Chamber Foundation, 2012), are an important group of consumers due to the role they play in today's economy. The latest marketing reports (GfK, 2018) indicate that they spend more money, and exert a bigger influence on the choice of many products and services for the entire household. The materialistic lifestyle seems to be an integral part of modern life for teenage consumers (Twenge \& Kasser, 2013). Unfortunately, greater materialism among teenagers is also associated with addiction to new technology (Gentina \& Rowe, 2020), compulsive buying (Islam et al., 2017), emotion dysregulation (Estévez et al., 2020), and depression (Mueller et al., 2011). In adolescence, building one's own identity is the most important developmental task (Erikson, 1968) and, for young consumers, material goods serve as a source of power by helping them to build their position within their peer group (Banerjee \& Dittmar, 2008), as self-image communicators, as a way to compensate for the deficiencies of self-image (Chaplin \& John, 2007; Chaplin et al., 2014; Wicklund \& Gollwitzer, 1981), and for the protection of one's image (Munichor \& Steinhart, 2016).

Although most studies treat adolescents as a homogeneous group, research on age differences in the materialistic behavior of adolescents indicates there is an age effect during this period in their lives (Gentina \& Rowe, 2020). Research has shown differences regarding the use of and attitudes towards material goods as they may be related to self-esteem, which change during adolescence (Chaplin \& John, 2007, 2010; Zawadzka \& Lewandowska-Walter, 2016). Furthermore, younger adolescents have higher levels of social conformity to norms and need more social support compared to late adolescents (Berndt, 1979). Therefore, we are interested to ascertain whether adolescents differ in their consumption habits depending on the stage of their development.

Notwithstanding the above observations, much of the research indicates a dependence between materialism and the role of material goods in building the concept of oneself (Lee et al., 2020; Razmus et al., 2020); however, little is known about this among adolescents. Therefore, we applied the moderated mediation model to investigate this association and the underlying mechanisms between materialism and BESC among Generation $\mathrm{Z}$ students.

\section{LITERATURE REVIEW AND HYPOTHESES}

\section{FROM MATERIALISM TO BRAND ENGAGEMENT}

The prevailing literature on marketing points to the huge role played by materialism in consumer deci- sions (Goldsmith et al., 2012). While materialism has been intensively debated since the 1990s (Sabah, 2017), its role in the lives of adolescents has seldom been studied (e.g. Chaplin \& John, 2007, 2010; Gentina \& Rowe, 2020; Zawadzka \& Iwanowska, 2016; Zawadzka et al., 2018).

Materialism is defined from several different perspectives. The two main approaches to interpreting materialism see it either as a personality trait, i.e., the importance a person attaches to their possessions (Belk, 1984), or as a value system in which possession is at the center of everything (Richins \& Dawson, 1992). Shrum expands these concepts and argues that it helps consumers to shape and maintain their identity (Shrum et al., 2014).

Materialism among adolescents includes the need to buy things, the enjoyment of possessions, and the desire to acquire and secure money for purchases (Goldberg et al., 2003). Previous studies on teenagers have shown that materialism contributes to excessive consumption and impulsive purchases, and is a predictor of compulsive buying behavior (Islam et al., 2017). Research also shows that adolescents rejected by their peers demonstrate a higher level of materialism than peers who are accepted in the group (Jiang et al., 2015), and that adolescents whose self-concept is particularly unstable are especially prone to sourcing and consuming items to impress others (Chaplin \& John, 2007).

The modern term corresponding to materialism is brand engagement in self-concept (BESC). Materialism is a broader global construct and means assigning excessive importance to the possession of material goods (Belk, 1984; Flynn et al., 2016; Richins \& Dawson, 1992). In turn, according to Sprott et al. (2009), BESC is a consumer's tendency to differentiate themselves by integrating a brand with their self-concept. This global disposition is an important individual variable that characterizes consumers. The BESC shows consumers along a continuum from the lowest end, where brands are unimportant to their sense of self, to the highest end, where they identify strongly with brands.

The concept of BESC, also important for researchers and practitioners (Razmus et al., 2017), constitutes a niche area in the broader context of brand (Ismail et al., 2021).

The evidence contained in the literature is scarce regarding the relationship between brand engagement and specific marketplace behaviors (Flynn et al., 2016); however, studies show a significant positive correlation between BESC and attitudes toward shopping among genders (Goldsmith \& Goldsmith, 2012). Taking certain brands into account in one's own self-concept is, therefore, a consequence of the desire to build and maintain an appropriate image (Razmus et al., 2017). Thus, we can formulate the following hypothesis:

$\mathrm{H} 1$ : Materialism is positively correlated with BESC. 


\section{FROM MATERIALISM TO CONSPICUOUS CONSUMPTION}

Like materialism, conspicuous consumption (CC) refers to a behavior in which an individual shows wealth by purchasing and consuming luxury goods (Trigg, 2001). CC is also often defined as the tendency of consumers to show their social status and self-image through the visually observable products they consume (Chipp et al., 2011). Therefore, the basic motivation to purchase visible goods is prestige (Belk, 1988; Wu et al., 2017), and it follows that the satisfaction with the product often results from the reaction of recipients and not from the actual use of the product (Shao et al., 2019). There are relatively few studies that set out to analyze the relationship between psychological factors and attitudes towards conspicuous consumption during adolescence (Velov et al., 2014). Studies have identified materialism and CC as being related but also as different theoretical constructs (Podoshen et al., 2011). The accumulation of material goods is the essence of materialism, whereas demonstration of one's possessions is the defining element of consumption (Velov et al., 2014). Conspicuous consumption is especially attractive to materialists interested in the symbolic meaning of products (Richins, 1994) and materialistic values have a significant impact on CC orientation (Podoshen et al., 2011).

Several studies have linked materialism to symbolic consumption (Prendergast \& Wong, 2003), as well as CC (Segal \& Podoshen, 2013), suggesting that highly materialist consumers tend to buy expensive products more ostentatiously than low-materialist consumers (Wu et al., 2017). The association between materialism and CC is also confirmed by the results of research on luxury goods (Chan et al., 2015). Furthermore, as it is well known that teenagers closely follow their peers, it is very likely that they pay attention to the way they are perceived by others (Brown \& Lohr, 1987). For young people, the acquisition of expensive goods and services is often used as a tool for gaining social recognition (Banerjee \& Dittmar, 2008).

Some researchers explicitly posit materialism as an antecedent of the level of a brand's integration into consumers' self-concept (Rindfleisch et al., 2009). Thus, conspicuous consumption, as a more specific behavioral pattern than materialism, may be at least partially a consequence of this materialism.

Therefore, the following hypothesis can be formulated:

$\mathrm{H} 2$ : Materialism is positively associated with conspicuous consumption.

\section{FROM CONSPICUOUS CONSUMPTION TO BESC}

Research indicates that one of the factors mediating between materialism and BESC might be so-called status consumption or conspicuous consumption (Flynn et al., 2016; Rehman et al., 2019). In terms of meaning, status consumption and conspicuous consumption are similar phenomena (O'Cass \& McEwen, 2004); therefore, the relationship between conspicuous consumption and BESC can be understood as analogous with the relationship between status consumption and BESC.

The inclination to consume for prestige stems in part from materialism (Kasser, 2002; Lertwannawit \& Mandhachitara, 2012), and results in other market behaviors such as using brands to build self-concept and the social self. Brands can represent attributes important to a particular group, and their purchase stems from the desire to achieve a desired image within a certain reference group (Goldsmith et al., 2012). The relation between status consumption and BESC is, therefore, positive (Goldsmith et al., 2012).

However, conspicuous consumption and BESC differ conceptually and evolve from very different motivations. In the case of BESC, the consumer uses branded goods to enhance the perception of themselves and to create their own image, whereby brands do not have to be prestigious. Conspicuous consumption, on the other hand, refers to the image that people present to others. Previous studies suggest that status consumption mediates the relationship between materialism and BESC in adults (Flynn et al., 2016; Rehman et al., 2019), and we can therefore expect CC, although different from status consumption, to be linked to materialism and BESC. Therefore, we hypothesize that:

H3: Conspicuous consumption has a positive impact on BESC and mediates the relationship between materialism and BESC.

\section{THE ROLE OF TEENAGERS' AGE}

One of the most important developmental tasks for adolescents is shaping their own identity, so it can be expected that young consumers who want to develop their self-esteem will become more involved with brands (Hsiech \& Chang, 2016), because when adolescents choose certain brands they try to express their identity (Autio et al., 2016). Brands help to develop the self-concept in young consumers and social groups (Eisend \& Stokburger-Sauer, 2013). Experimentally, Goldsmith et al. (2012) and Flynn et al. (2011) found that BESC levels are higher in adolescents than in adults. Chaplin and John (2005) found that the importance of brand association increases with age, along with an increase in the depth of connections. Therefore, we hypothesize that:

H4: Age is associated with BESC.

The effect of age at different stages of adolescence is not well known (Hong et al., 2019). Understanding the importance of tangible goods for self-concept 
emerges around the same time as teenagers experience decline self-esteem (ages 12-13; Chaplin et al., 2014; Robins et al., 2002). In late adolescence (ages 15-18), material possessions play a lesser role which is associated with improved self-esteem (Chaplin et al., 2014; Zawadzka \& Lewandowska-Walter, 2016) and a more realistic self-concept, so adolescents no longer need to use as many coping strategies as possible (McCarthy \& Hoge, 1982). Their repertoire of strategies to enhance self-esteem and manage the experiences they communicate to others is also bigger (Chaplin \& John, 2007; McCarthy \& Hoge, 1982). Therefore, we hypothesize that:

H5: Age negatively moderates the relationship between $\mathrm{CC}$ and BESC.

\section{THE CONCEPTUAL MODEL}

Hypotheses formulated from the cited research literature on materialism indicate that higher adolescent materialism leads to higher conspicuous consumption of products and brands. We propose a moderated mediation model, where conspicuous consumption partially mediates the relationship between materialism and BESC, with age moderating the relationship between conspicuous consumption and BESC (Figure 1).

\section{PARTICIPANTS AND PROCEDURE}

\section{PARTICIPANTS}

The study group consisted of 581 students aged 13 to $17(M=15$ years, $S D=1.42), 51.6 \%$ of whom were girls. As many as $75.4 \%$ of the students received pocket money $(\mathrm{Me}=\mathrm{PLN} 200) .2 .6 \%$ of teenagers described the financial status of the family as poor, $67.6 \%$ as middle-class, $28.2 \%$ as wealthy and $1.6 \%$ as very wealthy. The examined sample enables the identification of correlations in the population of at least $r=.10$ with a probability of $1-\beta=0.80$ (one-tailed test).

\section{PROCEDURE}

The first step was to obtain ethical approval from the ethics committee at the appropriate university. We also contacted the schools to obtain consent for data collection. All students whose parents consented to the study and who themselves agreed to participate were included in the study.

The data were collected through individual interviews. Before responding, the respondents were trained by the researcher to use the Likert scale. The scale was printed separately in A4 format, and the subject had it in front of them during the examination. The study was conducted without financial gratification and participants were assured of anonymity.

Out of 5 product categories, the interviewer chose one category that was familiar to the respondent (see Table 1). The respondent was then given the names of the brands in the selected category on individual cards, from which he or she initially chose the ones he or she knew. The researcher then selected the brand for the study. The researcher's choice was dependent on previous surveys, i.e., brands were chosen that were less frequently selected by previous respondents. This procedure ensured that an even number of respondents per brand was maintained.

In the next stage, a vivid image of one of the selected brands was induced. The respondent's task in this stage was to imagine a typical user of the brand in question, after being instructed to do so.

The survey started with the Youth Materialism Scale (YMS), Conspicuous Consumption Scale, and the BESC Scale. Next, participants answered questions about socio-demographic data.

\section{MEASURES}

Materialism. We measured teenagers' materialism using the 10-item YMS scale from Goldberg et al. (2003), Polish adaptation (Zawadzka \& Lewandowska-Walter, 2016). The scale measures materialism,

\section{Figure 1}

Moderated mediation model of the relationship between materialism and brand engagement in self-concept

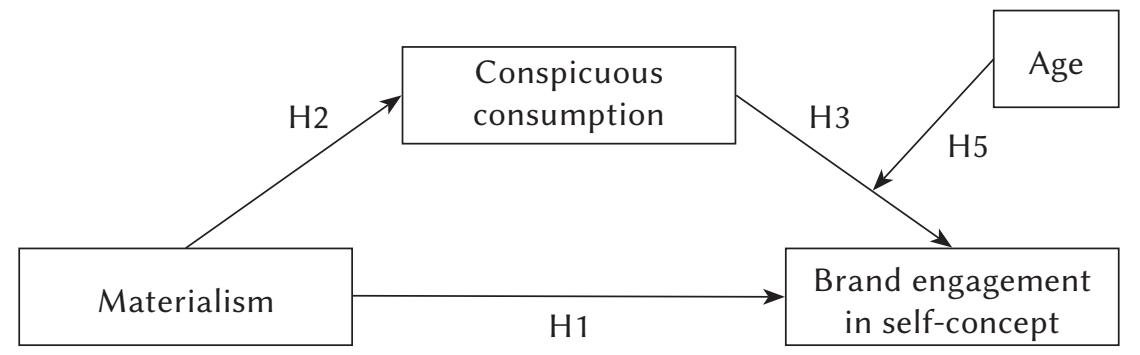


defined as the desire to purchase products and brands, the desire to have goods and money to purchase them, and to have a job that provides the ability to purchase. The reliability of the scale in the present study sample was $\alpha=.81$

Conspicuous consumption. To measure conspicuous consumption, we used the scale of Souiden et al. (2011), self-translation, which consists of five items (e.g. "I purchase branded accessories because they make me gain respect"). Cronbach's $\alpha$ reliability in this study was $\alpha=.92$.

Brand engagement in self-concept. BESC (Sprott et al., 2009) was measured with the Polish version of the scale (Razmus, 2012), which includes 4 items in its shortened version. Cronbach's $\alpha$ reliability of the scale was $\alpha=.87$.

\section{MODEL ESTIMATION}

A moderated mediation model (Figure 1) was tested by using the Hayes (2013) PROCESS macro (Model 14) with the mean composite scores on the items for materialism, CC, and BESC. The analysis assessed (1) the effects of materialism on BESC, (2) the effects of materialism on CC and (3) the effect of CC on BESC (as moderated by age). The $95 \%$ bias-corrected confidence interval from 5000 resamples was generated by the bias-corrected bootstrapping method to evaluate the statistical significance of the correlation and effects.

\section{RESULTS}

\section{DESCRIPTIVE STATISTICS}

The descriptive statistics and correlations between the variables materialism, conspicuous consumption and BESC are presented in Table 2.

Inspection of the correlations shows that materialism is positively correlated with conspicuous consumption (boot 95\% $\mathrm{CI}=[0.56,0.67])$ and positively correlated with BESC (boot $95 \% \mathrm{CI}=[0.31,0.47]$ ). The correlation findings also reveal that conspicuous consumption is significantly correlated with brand engagement in self-concept (boot 95\% CI $=[0.46,0.60]$ ). In addition, age was negatively related only to conspicuous consumption (boot $95 \% \mathrm{CI}=[-0.17$, $-0.01])$.

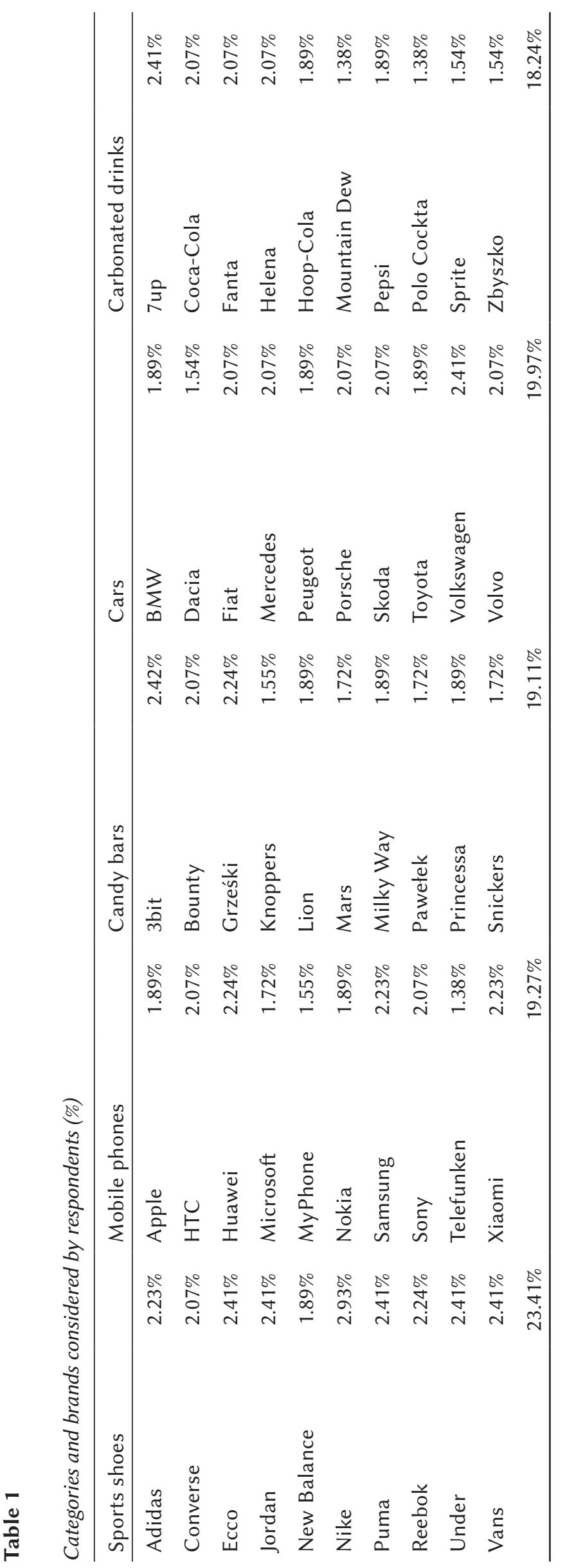


Table 2

Means, standard deviations, and Pearson's $r$ correlations

\begin{tabular}{|c|c|c|c|c|c|}
\hline \multirow[t]{2}{*}{ Variables } & \multicolumn{2}{|c|}{$\begin{array}{l}\text { Descriptive statistics } \\
(\text { boot } 95 \% \mathrm{Cl})\end{array}$} & \multicolumn{3}{|c|}{$\begin{array}{c}\text { Pearson's } r \text { correlation coefficients } \\
\text { (boot } 95 \% \mathrm{Cl} \text { ) }\end{array}$} \\
\hline & M & $S D$ & 1 & 2 & 3 \\
\hline \multirow[t]{2}{*}{ 1. Materialism } & 3.82 & 1.01 & & & \\
\hline & $(3.75,3.91)$ & $(0.95,1.07)$ & & & \\
\hline \multirow[t]{2}{*}{ 2. Conspicuous consumption } & 3.23 & 1.44 & .62 & & \\
\hline & $(3.12,3.35)$ & $(1.36,1.51)$ & $(.56, .67)$ & & \\
\hline \multirow{2}{*}{$\begin{array}{l}\text { 3. Brand engagement } \\
\text { in self-concept }\end{array}$} & 4.02 & 1.41 & .39 & .53 & \\
\hline & $(3.90,4.13)$ & $(1.35,1.48)$ & $(.31, .47)$ & $(.46, .60)$ & \\
\hline \multirow[t]{2}{*}{ 4. Age } & 15.02 & 1.41 & -.01 & -.09 & -.05 \\
\hline & - & - & $(-.09, .07)$ & $(-.13, .03)$ & $(-.17,-.01)$ \\
\hline
\end{tabular}

\section{Figure 2}

\section{Moderated mediation model}

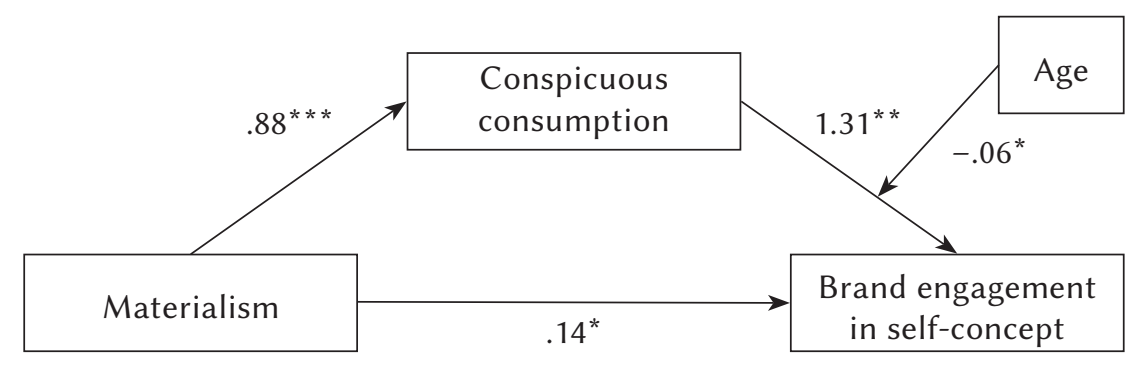

Note. $N=581$. Unstandardized coefficients are presented. ${ }^{*} p<.05,{ }^{* *} p<.01,{ }^{* * *} p<.001$.

\section{Figure 3}

The moderating role of age

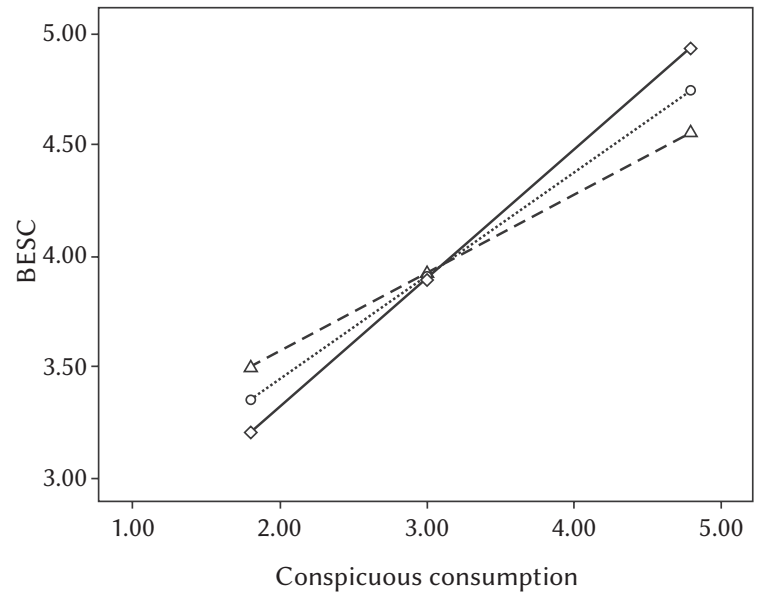

Age $\diamond 13$ years $\circ 14-16$ years $\Delta 17$ years

\section{MODERATED MEDIATION}

The next step was mediation and moderation analysis. The results (Figure 2) showed that materialism positively predicted conspicuous consumption $(95 \% \mathrm{CI}=[0.79$, 0.97]) as well as BESC $(95 \% \mathrm{CI}=[0.02,0.26])$. Conspicuous consumption $(95 \% \mathrm{CI}=[0.58,2.04])$ and age positively predicted brand engagement in self-concept (95\% CI $=[0.01,0.35])$. The interaction of conspicuous consumption and age negatively predicted brand engagement in self-concept $(95 \% \mathrm{CI}=[-0.10,-0.01])$, indicating that age significantly moderated the mediating effect of conspicuous consumption. In Figure 2, the results of the PROCESS macro are illustrated.

Figure 3 presents the BESC as a function of conspicuous consumption in different age groups. Conditional indirect effect analysis revealed that the indirect effect was more significant for early adolescents (13 years), effect $=0.51$, bootSE $=0.07$, boot $95 \% \mathrm{CI}=[0.36,0.66]$, than for those in middle adolescence (14-16 years), ef- 
fect $=0.41$, bootSE $=0.05$, boot $95 \% \mathrm{CI}=[0.31,0.51]$ and late adolescence (17 years), effect $=0.31$, bootSE $=0.06$, boot $95 \% \mathrm{CI}=[0.19,0.43]$. This means that conspicuous consumption mediates the relationship between materialism and BESC in each age group of teenagers, and the power of mediation declines with age.

\section{DISCUSSION}

The aim of the study was to investigate the relationship between materialism and adolescents' brand engagement in self-concept and to identify the potential mechanism of the way in which materialism would predict BESC. As expected, the results demonstrated a positive correlation between materialism and BESC, the mediating effect of CC, and the moderating effect of age.

\section{THE CORRELATION BETWEEN MATERIALISM AND BESC}

The results indicated that materialism positively predicted adolescent BESC, which was consistent with previous research within the adult consumer group (Flynn et al., 2016; Goldsmith et al., 2012). Our study shows that the more materialistic teenagers are, the more likely it is that they will construct themselves through brands. Choosing or using specific brands can be interpreted as shaping identity (Autio et al., 2016). Young people are looking for a way to build their identity, and brands can play a large part in this (Sirchuk, 2012).

\section{THE MEDIATING ROLE OF CONSPICUOUS CONSUMPTION}

The finding that materialism predicted adolescent BESC through the mediating effect of CC was consistent with Kasser's (2002) conceptualization of materialism, defined as a desire for goods and attributes ensuring status. However, the search for status is only one dimension of materialism (Belk, 1988). Brands have symbolic meaning and can be used to build one's image within a group (Goldsmith et al., 2012). Thus, consumers' signs of status may be explained, among other things, by valuing materialistic behavior (Flynn et al., 2016). The propensity for conspicuous consumption is partly driven by materialism (Lertwannawit \& Mandhachitara, 2012) and subsequently drives other market behaviors, including brand engagement.

\section{THE MODERATING ROLE OF AGE}

The results illustrated that age moderated the relationship between conspicuous consumption and
BESC, which confirms the assumption that adolescents, depending on their development stage, have different approaches to their materialistic behavior (Gentina \& Rowe, 2020). Specifically, for early adolescents, the mediating role of conspicuous consumption was stronger than for middle and late adolescents. These results confirm certain tendencies in teenagers' materialistic behavior. In late childhood and early adolescence (12-13 years of age), the level of materialism increases along with a decrease in self-esteem. At this stage teenagers develop market knowledge, concepts and ideas related to brands (John, 1999), and these changes are accompanied by consumption. Adolescents also acquire certain goods to belong to a specific social group (Auty \& Elliott, 2001). In addition, social belonging, the need for peer support, and higher conformity to social norms are characteristic of younger adolescents (Berndt, 1979). They use material goods to shape their identity and gain prestige (Belk, 1988) as well as to fulfill needs in terms of individualization and social interaction, personalization and group membership (Chan et al., 2013). Teenagers use brands to create their image by purchasing the brands used by their peer groups to gain their approval (Auty \& Elliott, 2001).

On the other hand, research has shown that in the period of late adolescence (16-18 years of age), the level of conspicuous consumption decreases, which is associated with a lower need for brand engagement in self-concept. During this time, older adolescents gain greater personal autonomy, become more realistic as regards their own conceptions, and feel better in the social setting, so they need fewer management strategies to overcome low self-esteem (McCarthy \& Hoge, 1982).

\section{LIMITATIONS AND DIRECTIONS FOR FUTURE RESEARCH}

The present research is not without certain limitations. First, the research is based on materialism patterns in Polish adolescents, which limits the cultural generalizability of the results. The second limitation is its cross-sectionality, which does not allow conclusions to be established on cause-and-effect relationships. In the future, a longitudinal study would be required to assess the mutual influence of the variables analyzed in the study.

The results indicate that adolescents who are high on the materialism scale build their self-image through the brands whose products they consume. Future research should compare these results with the results of an analogous analysis of older consumers, e.g., in early adulthood. Moreover, future research could analyze how brand image influences the creation of self-concept, i.e., which characteristics are desirable, and which are undesirable for teenagers. 


\section{IMPLICATIONS}

Answering the question as to what makes young people use brands to shape their self-concept is intriguing, but also important for a wider audience - parents, teachers, therapists, scholars, and market researchers. The results of the research indicate that materialism and ostentatious consumption may be related to building one's self through brands, which is particularly evident in younger adolescents, and may be related to a drop in self-esteem at this stage of life (Chaplin \& John, 2007).

The study was designed to show general trends among teenagers, and so it was conducted in the context of 5 product categories and 50 brands. The use of different categories of products consumed in public allows for a wider range of generalizations of the findings. For these categories, we see that younger teenagers who are oriented towards ostentatious consumption are also more materialistic, which leads them to construct themselves through brands. So, brands that emphasize prestige and position themselves as more luxurious may reinforce these effects, which in turn may lead to greater consumption of these brands.

From a psychological point of view, it is important to support and build among adolescents various strategies to meet their own needs and build self-concept in order to reduce the risk of over-attachment to material goods and the consolidation of this tendency as a way to build self-esteem. Being aware that materialism is linked to the construction of self through brands can highlight the importance of helping teenagers to also develop their identity based on other values and deeper, more interpersonal relationships.

\section{CONCLUSIONS}

Despite its limitations, the study is an essential step in uncovering the mechanism of BESC by pointing out that materialism could positively predict adolescent brand engagement in self-concept directly and indirectly through conspicuous consumption. Age acts as a moderator and the mediating effect of $\mathrm{CC}$ between materialism and adolescents' BESC is stronger in the case of younger adolescents.

\section{FUNDING SOURCE}

This paper is supported by the National Science Centre (Poland) under a PRELUDIUM 13 Grant (2017/25/N/ HS4/02510) to Magdalena Kolańska-Stronka.

\section{References}

Autio, M., Lähteenmaa, J., Holmberg, U., \& Kujala, J. (2016). Young consumer identity in a restrictive school environment - addictive substances, sym- bolic goods and consumer skills. Children and Youth Services Review, 68, 100-106. https://doi. org/10.1016/j.childyouth.2016.07.003

Auty, S., \& Elliott, R. (2001). Being like or being liked: Identity vs. approval in a social context. Advances in Consumer Research, 28, 235-241.

Banerjee, R., \& Dittmar, H. (2008). Individual differences in children's materialism: The role of peer relations. Personality and Social Psychology Bulletin, 34, 17-31. https://doi.org/10.1177/0146167207309196

Belk, R.W. (1984). Three scales to measure constructs related to materialism: Reliability, validity and relationships to measures of happiness. Advances in Consumer Research, 11, 291-297.

Belk, R. W. (1988). Possessions and the extended self. Journal of Consumer Research, 15, 139-168. https:// doi.org/10.1086/209154

Berndt, T. J. (1979). Developmental changes in conformity to peers and parents. Developmental Psychology, 15, 608-616. https://doi.org/10.1037/00121649.15.6.608

Brown, B. B., \& Lohr, M. J. (1987). Peer-group affiliation and adolescent self-esteem: an integration of ego-identity and symbolic-interaction theories. Journal of Personality and Social Psychology, 52, 47-55. https://doi.org/10.1037//0022-3514.52.1.47

Chan, K., Leung Ng, Y., \& Luk, E. K. (2013). Impact of celebrity endorsement in advertising on brand image among Chinese adolescents. Young Consumers, 14, 167-179. https://doi.org/10.1108/17473611311325564

Chan, W.Y., To, C. K., \& Chu, W. C. (2015). Materialistic consumers who seek unique products: How does their need for status and their affective response facilitate the repurchase intention of luxury goods? Journal of Retailing and Consumer Services, 27, 1-10. https://doi.org/10.1016/j.jretconser.2015.07.001

Chaplin, L. N., Hill, R. P., \& John, D. R. (2014). Poverty and materialism: a look at impoverished versus affluent children. Journal of Public Policy \& Marketing, 33, 78-92. https://doi.org/10.1509/jppm. 13.050

Chaplin, L. N., \& John, D. (2005). The development of self-brand connections in children and adolescents. Journal of Consumer Research, 32, 119-129. https://doi.org/10.1086/426622

Chaplin, L. N., \& John, D. R. (2007). Growing up in a material world: Age differences in materialism in children and adolescents. Journal of Consumer Research, 34, 480-493. https://doi.org/10.1086/518546

Chaplin, L. N., \& John, D. R. (2010). Interpersonal influences on adolescent materialism: a new look at the role of parents and peers. Journal of Consumer Psychology, 20, 176-184. https://doi.org/10.1016/j. jcps.2010.02.002

Chipp, K., Kleyn, N., \& Manzi, T. (2011). Catch up and keep up: Relative deprivation and conspicuous consumption in an emerging market. Journal of International Consumer Marketing, 23, 117-134. https://doi.org/10.1080/08961530.2011.543053 
Eisend, M., \& Stokburger-Sauer, N. E. (2013). Brand personality: a meta-analytic review of antecedents and consequences. Marketing Letters, 24, 205-216. https://doi.org/10.1007/s11002-013-9232-7

Erikson, E. (1968). Identity: Youth and crisis. Norton.

Estévez, A., Jauregui, P., Granero, R., Munguía, L., López-González, H., Macía, L., López, N., Momeñe, J., Corral, S., Fernández-Aranda, F., Agüera, Z., MenaMoreno, T., Lozano-Madrid, M., Vintró-Alcaraz, C., Del Pino-Gutierrez, A., Codina, E., Valenciano-Mendoza, E., Gómez-Peña, M., Moragas, L., Casalé, G., ... Jiménez-Murcia, S. (2020). Buying-shopping disorder, emotion dysregulation, coping and materialism: a comparative approach with gambling patients and young people and adolescents. International Journal of Psychiatry in Clinical Practice, 24, 407-415. https:// doi.org/10.1080/13651501.2020.1780616

Flynn, L. R., Goldsmith, R. E., \& Korzenny, F. (2011). Brand engagement in self-concept: a psychometric and demographic analysis. Journal of Multidisciplinary Research, 3, 5-18.

Flynn, L. R., Goldsmith, R. E., \& Pollitte, W. (2016). Materialism, status consumption, and market involved consumers. Psychology \& Marketing, 33, 761-776. https://doi.org/10.1002/mar.20915

Gentina, E., \& Rowe, F. (2020). Effects of materialism on problematic smartphone dependency among adolescents: The role of gender and gratifications. International Journal of Information Management, 54, 102134. https://doi.org/10.1016/j.ijinfomgt.2020.102134

GfK (2008). Junior Shopper 2018. Dzieci i nastolatki jako kupujący oraz decydenci [Children and teenagers as buyers and decision makers]. Retrieved from https://www.gfk.com/pl/prasa/co-drugiedziecko-w-polsce-posiada-wlasne-oszczednosciponad-polowa-dysponuje-wlasnym-budzetem

Goldberg, M. E., Gorn, G. J., Peracchio, L. A., \& Bamossy, G. (2003). Understanding materialism among youth. Journal of Consumer Psychology, 13, 278288. https://doi.org/10.1207/s15327663jcp1303_09

Goldsmith, R. E., Flynn, L. R., \& Clark, R. A. (2012). Materialistic, brand engaged and status consuming consumers and clothing behaviors. Journal of Fashion Marketing and Management, 16, 102-119. https://doi.org/10.1108/13612021211203050

Goldsmith, R. E., \& Goldsmith, E. B. (2012). Brand personality and brand engagement. American Journal of Management, 12, 11-20.

Hayes, A. F. (2013). Introduction to mediation, moderation, and conditional process analysis: Methodology in the social sciences. Guildford Press.

Hong, J. K., Oh, M., Bong, G., Kim, J. H., Bahn, G., Cho, I. H., \& Yoo, H. J. (2019). Age as a moderator of social skills intervention response among Korean adolescents with autism spectrum disorder. Journal of Autism and Developmental Disorders, 49, 16261637. https://doi.org/10.1007/s10803-018-3859-4
Hsieh, S. H., \& Chang, A. (2016). The psychological mechanism of brand co-creation engagement. Journal of Interactive Marketing, 33, 13-26. https:// doi.org/10.1016/j.intmar.2015.10.001

Islam, T., Wei, J., Sheikh, Z., Hameed, Z., \& Azam, R. I. (2017). Determinants of compulsive buying behavior among young adults: The mediating role of materialism. Journal of Adolescence, 61, 117-130. https://doi.org/10.1016/j.adolescence.2017.10.004

Ismail, A. R., Nguyen, B., Chen, J., Melewar, T. C., \& Mohamad, B. (2021). Brand engagement in selfconcept (BESC), value consciousness and brand loyalty: a study of generation $\mathrm{Z}$ consumers in Malaysia. Young Consumers, 22, 112-130. https://doi. org/10.1108/YC07-2019-1017

Jiang, J., Zhang, Y., Ke, Y., Hawk, S. T., \& Qiu, H. (2015). Can't buy me friendship? Peer rejection and adolescent materialism: Implicit self-esteem as a mediator. Journal of Experimental Social Psychology, 58, 48-55. https://doi.org/10.1016/j.jesp.2015.01.001

John, D. R. (1999). Consumer socialization of children: a retrospective look at twenty-five years of research. Journal of Consumer Research, 26, 183-213. https://doi.org/10.1086/209559

Kasser, T. (2002). The high price of materialism. MIT Press.

Lee, M., Bae, J., \& Koo, D. M. (2020). The effect of materialism on conspicuous vs. inconspicuous luxury consumption: Focused on need for uniqueness, self-monitoring and self-construal. Asia Pacific Journal of Marketing and Logistics, 33, 869-887. https://doi.org/10.1108/apjml-12-2019-0689

Lertwannawit, A., \& Mandhachitara, R. (2012). Interpersonal effects on fashion consciousness and status consumption moderated by materialism in metropolitan men. Journal of Business Research, 65, 1408-1416. https://doi.org/10.1016/j.jbusres.2011. 10.006

McCarthy, J. D., \& Hoge, D. R. (1982). Analysis of age effects in longitudinal studies of adolescent selfesteem. Developmental Psychology, 18, 372-379. https://doi.org/10.1037/0012-1649.18.3.372

Mueller, A., Mitchell, J. E., Peterson, L. A., Faber, R. J., Steffen, K. J., Crosby, R. D., \& Claes, L. (2011). Depression, materialism, and excessive Internet use in relation to compulsive buying. Comprehensive Psychiatry, 52, 420-424. https://doi.org/10.1016/j. comppsych.2010.09.001

Munichor, N., \& Steinhart, Y. (2016). Saying no to the glow: When consumers avoid arrogant brands. Journal of Consumer Psychology, 26, 179-192. https://doi.org/10.1016/j.jcps.2015.05.004

National Chamber Foundation (2012). The Millennial generation research review. US Chamber of Commerce.

O'Cass, A., \& McEwen, H. (2004). Exploring consumer status and conspicuous consumption. Journal of Consumer Behaviour, 4, 25-39. https://doi. org/10.1002/cb.155 
Podoshen, J. S., Li, L., \& Zhang, J. (2011). Materialism and conspicuous consumption in China: a crosscultural examination. International Journal of Consumer Studies, 35, 17-25. https://doi.org/10.1111/ j.1470-6431.2010.00930.x

Prendergast, G., \& Wong, C. (2003). Parental influence on the purchase of luxury brands of infant apparel: an exploratory study in Hong Kong. Journal of Consumer Marketing, 20, 157-169. https:// doi.org/10.1108/07363760310464613

Razmus, W. (2012). Skala Konstruowania Siebie przez Marki (KSM): Polska adaptacja skali Brand Engagement in Self-Concept (BESC) [Polish adaptation of the Brand Engagement in Self-Concept Scale]. Marketing i Rynek, 8, 15-19.

Razmus, W., Jaroszyńska, M., \& Palęga, M. (2017). Personal aspirations and brand engagement in selfconcept. Personality and Individual Differences, 105, 294-299. https://doi.org/10.1016/j.paid.2016.10.018

Razmus, W., Mazzoli, V., Acuti, D., \& Grabner-Kräuter, S. (2020). Brand engagement in self-concept: a comparative study in Austria, Italy and $\mathrm{Po}^{-}$ land. Journal of Consumer Marketing, 37, 785-794. https://doi.org/10.1108/jcm-09-2019-3412

Rehman, Z., Baharun, R., Salleh, N. Z. M., \& Sarwar, F. (2019). The mediating role of status consumption on the relationship of materialism and brand engagement in self-concept. International Journal of Recent Technology and Engineering, 8, 618-623.

Richins, M. L. (1994). Valuing things: The public and private meanings of possessions. Journal of Consumer Research, 21, 504-521. https://doi.org/10.1086/209414

Richins, M. L., \& Dawson, S. (1992). A consumer values orientation for materialism and its measurement: Scale development and validation. Journal of Consumer Research, 19, 303-316. https://doi.org/ 10.1086/209304

Rindfleisch, A., Burroughs, J. E., \& Wong, N. (2009). The safety of objects: Materialism, existential insecurity, and brand connection. Journal of Consumer Research, 36, 1-16. https://doi.org/10.1086/595718

Robins, R. W., Trzesniewski, K. H., Tracy, J. L., Gosling, S. D., \& Potter, J. (2002). Global self-esteem across the life span. Psychology and Aging, 17, 423-434. https://doi.org/10.1037/0882-7974.17.3.423

Sabah, S. (2017). The impact of self-construal and selfconcept clarity on socially motivated consumption: The moderating role of materialism. Journal of Global Scholars of Marketing Science, 27, 31-45. https://doi.org/10.1080/21639159.2016.1265321

Segal, B., \& Podoshen, J. S. (2013). An examination of materialism, conspicuous consumption and gender differences. International Journal of Consumer Studies, 37, 189-198. https://doi.org/10.1111/j.14706431.2012.01099.x

Sirchuk, J. (2012). Building brand loyalty through youth consumers and the use of grass roots consumer marketing. California Polytechnic State University.
Shao, W., Grace, D., \& Ross, M. (2019). Consumer motivation and luxury consumption: Testing moderating effects. Journal of Retailing and Consumer Services, 46, 33-44. https://doi.org/10.1016/j.jretconser.2018.10.003

Shrum, L. J., Lowrey, T. M., Pandelaere, M., Ruvio, A. A., Gentina, E., Furchheim, P., Herbert, M., Hudders, L., Lens, I., Mandel, N., Nairn, A., Samper, A., Soscia, I., \& Steinfield, L. (2014). Materialism: The good, the bad, and the ugly. Journal of Marketing Management, 30, 1858-1881. https://doi.org/10.1080/026725 7X.2014.959985

Souiden, N., M'Saad, B., \& Pons, F. (2011). A crosscultural analysis of consumers' conspicuous consumption of branded fashion accessories. Journal of International Consumer Marketing, 23, 329-343. https://doi.org/10.1080/08961530.2011.602951

Sprott, D., Czellar, S., \& Spangenberg, E. (2009). The importance of a general measure of brand engagement on market behavior: Development and validation of a scale. Journal of Marketing Research, 46, 92-104. https://doi.org/10.1509/jmkr.46.1.92

Trigg, A. (2001) Veblen, Bourdieu, and conspicuous consumption. Journal of Economic Issues, 35, 99115. https://doi.org/10.1080/00213624.2001.11506342

Twenge, J. M., \& Kasser, T. (2013). Generational changes in materialism and work centrality, 1976-2007. Personality and Social Psychology Bulletin, 39, 883897. https://doi.org/10.1177/0146167213484586

Wicklund, R. A., \& Gollwitzer, P. M. (1981). Symbolic self-completion, attempted influence, and self-deprecation. Basic and Applied Social Psychology, 2, 89114. https://doi.org/10.1207/s15324834basp0202_2

Wu, Z., Luo, J., Schroeder, J. E., \& Borgerson, J. L. (2017). Forms of inconspicuous consumption: What drives inconspicuous luxury consumption in China? Marketing Theory, 17, 491-516. https://doi. org/10.1177/1470593117710983

Velov, B., Gojković, V., \& Đurić, V. (2014). Materialism, narcissism and the attitude towards conspicuous consumption. Psihologija, 47, 113-129. https://doi. org/10.2298/psi1401113v

Zawadzka, A. M., \& Iwanowska, M. (2016). Explicit and implicit materialism vs. self-esteem and readiness for self-improvement in young people. Roczniki Psychologiczne, 19, 723-743. https://doi. org/10.18290/rpsych.2016.19.4-3en

Zawadzka, A. M., Iwanowska, M., \& Borchet, J. (2018). The role of parents, social media and materialism in teenage activism. Social Psychological Bulletin, 13, 1-17. https://doi.org/10.32872/spb.v13i4.26706

Zawadzka, A. M., \& Lewandowska-Walter, A. (2016). Wartości, style przywiązania i samoocena a materializm nastolatków [Values, attachment styles and self-esteem vs. adolescents' materialism. Polskie Forum Psychologiczne, 21, 394-409. https://doi. org/10.14656/PFP20160305 